\title{
Potensi Beberapa Ekstrak Tumbuhan Asteraceae sebagai Antioksidan dan Antiglikasi
}

\section{The Potency of Asteraceae Plants Extracts as Antioxidant and Antiglycation Agent}

\author{
Penulis \\ Eka Budiarti ${ }^{1}$, Irmanida Batubara ${ }^{1,2}$, Auliya IImiawati ${ }^{1}$ \\ Afiliasi
${ }^{1}$ Departemen Kimia, Fakultas Matematika dan IImu Pengetahuan Alam, IPB University, Bogor, Jawa Barat, 16680, Indonesia.
${ }^{2}$ Pusat Studi Biofarmaka Tropika, IPB University, Indonesia.

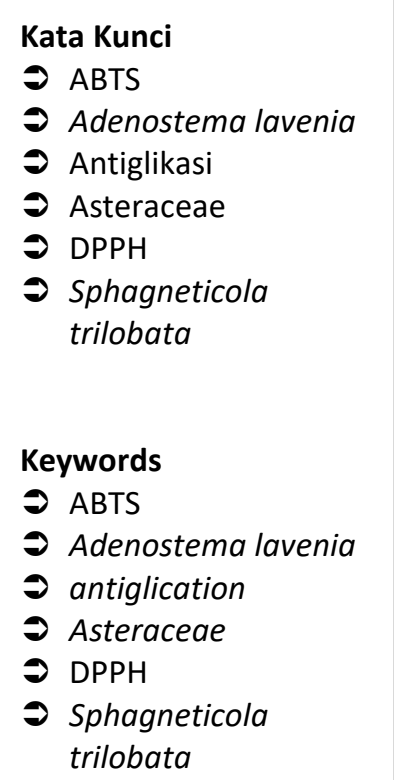

Diterima 5 Agustus2019 Direvisi 30 Oktober 2019 Disetujui 8 November 2019

*Penulis Koresponding Irmanida Batubara email: ime@apps.ipb.ac.id

\section{ABSTRAK}

Tumbuhan Asteraceae dilaporkan mengandung metabolit sekunder tinggi yang aktif sebagai antioksidan. Senyawa antioksidan juga digunakan untuk mencegah penuaan/reaksi glikasi. Penelitian ini bertujuan menentukan aktivitas antioksidan dan antiglikasi 7 tumbuhan Asteraceae. Daun Adenostema lavenia, Ageratum conyzoides, Dichrocephala integrifolia, Galinsoga parvifolia, Synedrella nodiflora, Mikania micrantha, dan Sphagneticola trilobata masing-masing diekstraksi menggunakan air. Ekstrak kemudian ditentukan kandungan total fenol, flavonoid, dan aktivitas antioksidan menggunakan metode 1,1-difenil-2-pikrilhidrazil (DPPH) dan 2,2'-azino-bis(3 ethylbenzothiazoline-6-sulfonic acid (ABTS), serta aktivitas antiglikasi. Ekstrak dengan kadar total fenolik dan flavonoid tertinggi adalah ekstrak M. micrantha. Ekstrak A. lavenia memiliki aktivitas antioksidan terhadap DPPH tertinggi dengan nilai $I_{50}$ sebesar 121,82 $\mu \mathrm{g} / \mathrm{mL}$ dan $A$. conyzoides tertinggi terhadap ABTS dengan kapasitas sebesar 4,51 mg trolox ekivalen (TE)/g ekstrak. Aktivitas antiglikasi tertinggi pada ekstrak G. parvifolia sebesar 90,67\% yang tidak berbeda nyata dengan ekstrak $A$. lavenia $(87,87 \%)$ dan $S$. trilobata (87,38\%). Secara keseluruhan ekstrak $A$. lavenia dan $S$. trilobata baik dikembangkan sebagai antioksidan dan antiglikasi.

\section{ABSTRACT}

Asteraceae plants are reported consisted of antioxidant component. Antioxidant also can be used to prevent aging/glycation reactions. This study aims to determine antioxidant and antiglycation activities of 7 Asteraceae plants. The leaves of Adenostema lavenia, Ageratum conyzoides, Dichrocephala integrifolia, Galinsoga parvifolia, Synedrella nodiflora, Mikania micrantha, and Sphagneticola trilobata were extracted using water. The total phenolic, total flavonoid content, antioxidant activity against 1,1-diphenyl-2pikrilhidrazil (DPPH) and 2,2'-azino-bis (3 ethylbenzothiazoline-6-sulfonic acid (ABTS), and antiglycation activities of all extract then were determined. The extract with the highest total phenolic and total flavonoid content was M. micrantha. A. lavenia extract had the highest antioxidant activity against DPPH with $I C_{50}$ of $121.82 \mu \mathrm{g} / \mathrm{mL}$, while $A$. conyzoides had the highest antioxidant activity against ABTS of $4.51 \mathrm{mg}$ trolox equivalent (TE)/g extract. The highest antiglycation activity was found on G. parvifolia extract of $90.67 \%$ which is not significantly different with the activity of A. lavenia extract (87.87\%) and S. trilobata (87.38\%). In general, A. Lavenia and $S$ trilobata could be developed as antioxidant and antiglycation agent. 


\section{PENDAHULUAN}

Glikasi adalah reaksi kimia nonenzimatik antara gula pereduksi dan gugus amino dari protein, asam nukleat atau fosfolipid akan membentuk Advanced glycation end product (AGEs) yang merupakan penyebab penuaan (Povichit et al. 2010). Selain reaksi glikasi, radikal bebas juga dapat memicu terbentuknya AGEs (Yagi et al. 2013). Untuk menghambat pembentukan AGEs dapat digunakan suatu bahan yang dapat menghambat reaksi glikasi dan radikal bebes seperti bahan antioksidan. Reaksi glikasi dapat dihambat menggunakan zat antiglikasi sedangkan radikal bebas dapat dihambat menggunakan antioksidan (Giancomoni dan Rein 2001).

Beragam cara dilakukan untuk mendapatkan bahan antiglikasi maupun antioksidan baik melalui jalur sintesis maupun menggunakan bahan alami. Selama ini tumbuhan dapat digunakan sebagai sumber antioksidan alami (Bernatoniene et al. 2011) dan juga dapat menjadi sumber antiglikasi. Di antara kerajaan plantae, famili Asteraceae merupakan famili terbesar kedua. Beberapa jenis tumbuhan famili ini dimanfaatkan sebagai antioksidan, antibakteri, dan antiinflamasi, hal ini disebabkan karena famili ini memiliki komponen senyawa bioaktif, seperti seskuiterpena, triterpen pentasiklik, diterpena, lakton, alkohol, alkaloid, tanin, polifenol, flavonoid, saponin, dan sterol yang dapat digunakan untuk bahan pengobatan (Wegiera et al. 2012; Erturk dan Demirbag 2003). Adenostemma lavenia merupakan salah satu jenis tumbuhan Asteraceae yang sering dianggap sebagai gulma/pengganggu namun memiliki kandungan yang bermanfaat. A. lavenia mengandung flavonoid, alkaloid, dan terpenoid yang tinggi (Kusumawati et al. 2003; Fauzan et al. 2017) yang berpotensi sebagai antioksidan (Stallings dan Lupo 2009). Berdasarkan penelitian yang telah dilaporkan, tumbuhan ini mengandung senyawa penghambat tirosinase dan antioksidan yaitu 11-hydroxylated kauranic acid (Ko et al. 2008, Fauzan et al 2017). Selain A. lavenia, tumbuhan Asteraceae lain juga berpotensi untuk dikembangkan sebagai antioksidan dan antiglikasi.

Pada penelitian ini digunakan A. lavenia dan 6 tumbuhan Asteraceae yang penampakannya mirip dengan $A$. lavenia dan diharapkan memiliki aktivitas antioksidan dan antiglikasi yang tinggi. Tumbuhan yang digunakan pada penelitian ini yaitu $A$. lavenia, Ageratum conyzoides, Dichrocephala integrifolia, Galinsoga parviflora, Synedrella nodiflora, Mikaina micrantha, dan Sphagneticola trilobata. Penelitian ini bertujuan menentukan aktivitas antioksidan dan antiglikasi ekstrak air 7 tumbuhan.

\section{METODE}

Bahan

Jenis tumbuhan yang digunakan yaitu $A$. lavenia, $A$. conyzoides, D. integrifolia, G. parviflora S. nodiflora, $M$. micrantha, dan S. Trilobata yang dikoleksi dari Unit Konservasi dan Budidaya Biofarmaka TropBRC di Darmaga, Bogor, Jawa Barat, Indonesia. Seluruh bahan tumbuhan dideterminasi di LIPI Biologi Cibinong Jakarta dan voucher specimen disimpan di Pusat Studi Biofarmaka Tropika LPPM IPB. Bahan kimia yang digunakan yaitu etanol 96\%, methanol 99.8\%, 2,2'diphenylpicryl hydrazyl (DPPH), asam askorbat, bovine serum albumin (BSA), dan 2,2'-azino-bis(3ethylbenzothiazoline-6-sulfonic acid (ABTS) yang dibeli dari Sigma-Aldrich, St Louis, Amerika Serikat; Glukosa, fruktosa, pereaksi Follin Ciocalteu, natrium karbonat, asam galat, aluminium klorida heksahidrat, kalium asetat, kuersetin, dan kalium persulfat dibeli dari Merck, Whitehouse station, Amerika Serikat; Buffer fosfat $(\mathrm{pH} \mathrm{7,4)}$ dan akuades.

\section{Preparasi Sampel}

Tujuh tumbuhan famili Asteraceae dibersihkan dan dikeringkan. Pengeringan dilakukan menggunakan oven pada suhu $40^{\circ} \mathrm{C}$. Setelah kering, masing-masing sampel digiling hingga menjadi serbuk dengan ukuran 80 mesh. Kemudian serbuk kering sampel ditentukan kadar air dan kadar abunya mengacu pada metode standar AOAC (2016).

\section{Ekstraksi Sampel}

Ekstraksi dilakukan dengan menggunakan pelarut air pada suhu $50^{\circ} \mathrm{C}$. Simplisia ditimbang sebanyak $20 \mathrm{~g}$, lalu dimasukkan ke dalam erlenmeyer dan ditambahkan pelarut dengan nisbah 1:10 selama 3 jam. Ekstrak disaring menggunakan kain blacu dan dilanjutkan dengan kertas saring Whatmann, lalu filtrat yang diperoleh dipekatkan dengan penguap putar hingga diperoleh ekstrak kering. Rendemen ekstrak kemudian ditentukan berdasarkan bobot keringnya menggunakan konversi kadar air.

\section{Penentuan Total Fenolik}

Penentuan total fenolik mengacu pada metode Singleton et al. (1999). Kandungan fenolik total ditentukan dengan pereaksi Folin-Ciocalteu menggunakan pelat 96-sumur. Dua puluh mikroliter ekstrak ditambahkan dengan $110 \mu \mathrm{L}$ pereaksi Folin- 
Ciocalteu lalu ditambahkan $70 \mu \mathrm{L}$ larutan natrium karbonat, diinkubasi pada suhu $25 \pm 2{ }^{\circ} \mathrm{C}$ selama 30 menit dan diukur absorbansnya pada panjang gelombang $765 \mathrm{~nm}$. Asam galat digunakan sebagai standar dengan konsentrasi 5, 10, 30, 50, 70, dan 100 $\mu \mathrm{g} / \mathrm{mL}$. Total fenolik dilaporan sebagai asam galat ekivalen (GAE)/g ekstrak.

\section{Penentuan Total Flavonoid}

Penentuan total flavonoid mengacu pada metode Lee et al. (2011). Kandungan flavonoid total ditentukan menggunakan aluminium klorida. Sebanyak $10 \mu \mathrm{L}$ ekstrak dicampur dengan $60 \mu \mathrm{L}$ metanol, $10 \mu \mathrm{L}$ aluminium klorida $(10 \% \mathrm{w} / \mathrm{v}), 10 \mu \mathrm{L}$ potassium asetat (1M), dan $110 \mu \mathrm{L}$ akuades pada pelat 96-sumur dan diinkubasi pada suhu ruang selama 30 menit. Absorbans diukur pada panjang gelombang $415 \mathrm{~nm}$. Kuersetin digunakan sebagai standar dengan deret konsentrasi sebesar 6,25, 12,5, 25, 50, dan $100 \mu \mathrm{g} / \mathrm{mL}$. Total flavonoid dilaporkan sebagai g kuersetin ekivalen (KE)/g ekstrak.

\section{Uji Aktivitas Antioksidan Metode DPPH.}

Penentuan aktivitas antioksidan DPPH mengacu pada metode Batubara et al. (2009). Seratus mikroliter ekstrak dan $100 \mu \mathrm{L}$ DPPH (2.45 mg DPPH dalam $50 \mathrm{~mL}$ etanol) ditambahkan ke dalam masing-masing sumur dari pelat 96-sumur. Setelah diinkubasi 30 menit pada suhu ruang, absorbans diukur pada panjang gelombang $514 \mathrm{~nm}$. Asam askorbat digunakan sebagai kontrol positif. Aktivitas antioksidan terhadap DPPH dilaporkan sebagai konsentrasi penghambatan radikal $50 \%$ (IC $\left.\mathrm{C}_{50}\right)$.

\section{Uji Aktivitas Antioksidan Metode ABTS.}

Penentuan aktivitas antioksidan ABTS mengacu pada metode Re et al. (1999). Larutan ABTS radikal disiapkan dengan cara mencampurkan $10 \mathrm{~mL}$ ABTS 7 mM dengan $5 \mathrm{~mL} \mathrm{~K}{ }_{2} \mathrm{~S}_{2} \mathrm{O}_{8}$ 2,45 mM selama $12-16$ jam di tempat gelap. Sebanyak $180 \mu \mathrm{L}$ ABTS radikal tersebut direaksikan dengan $20 \mu \mathrm{L}$ ekstrak dan diinkubasi pada suhu ruang selama 15 menit. Absorbans campuran kemudian diukur pada panjang gelombang $734 \mathrm{~nm}$. Trolox digunakan sebagai standar dan aktivitas antioksidan dilaporkan dalam mg Trolox ekivalen (TE)/g ekstrak.

\section{Uji Aktivitas Antiglikasi}

Penentuan aktivitas antiglikasi mengacu pada metode Povichit et al. (2010). Ekstrak masing-masing sampel dilarutkan dalam akuades sampai konsentrasi

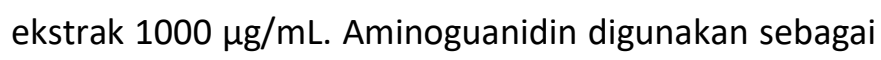
standar. Seluruh larutan uji tersebut diinkubasi pada suhu $60^{\circ} \mathrm{C}$ selama 40 jam. Setelah inkubasi, larutan kemudian dipipet sebanyak $100 \mu \mathrm{L}$ ke dalam sumur pelat 96-sumur. Jumlah relatif BSA yang terglikasi diukur menggunakan fluorometer pada panjang gelombang eksitasi $330 \mathrm{~nm}$ dan emisi $440 \mathrm{~nm}$.

\section{Analisis Statistika}

Analisis statistika diperlukan untuk mengetahui ada atau tidaknya perbedaan yang signifikan dari hasil yang diperoleh pada 7 ekstrak tumbuhan. Analisis statistika dilakukan menggunakan program SPSS 16.0 dengan analisis menggunakan One Way ANOVA dan dilanjutkan dengan analisis lanjutan berupa uji Duncan dengan menggunakan selang kepercayaan 95\%.

\section{HASIL DAN PEMBAHASAN \\ Kadar Air dan Kadar Abu}

Penentuan kadar air dan kadar abu dilakukan untuk mengetahui kualitas bahan yang digunakan, selain itu, kadar air juga digunakan sebagai koreksi untuk penentuan rendemen ekstrak. Kadar air dan kadar abu 7 sampel yang digunakan dapat dilihat pada Tabel 1 . Kadar air seluruh sampel berbeda nyata pada $\alpha=0,05$. G. parviflora memiliki kadar air tertinggi yaitu 9,29\% dan terendah dimiliki S. nodiflora yaitu 7,05\%. Kadar air yang baik adalah kadar air yang kurang dari 10\%, agar tumbuhnya jamur dan kapang pada bahan dapat dikurangi (Salamah dan Farahan 2014). Kadar air semua sampel yang digunakan tergolong baik menurut Farmakope Herbal Indonesia (FHI) dan Materia Medika Indonesia (MMI) (Ditjen POM 1995). Hal ini juga menunjukkan bahwa proses pengeringan sebelum analisis lebih lanjut telah berlangsung dengan baik.

Kadar abu digunakan untuk mengetahui kandungan mineral dalam suatu simplisia. Kadar abu tertinggi diperoleh pada $D$. integrifolia sebesar $13,86 \%$ dan kadar abu terendah pada S. trilobata sebesar 9,15\% yang tidak berbeda nyata dengan kadar abu A. lavenia. Semakin tinggi kadar abu simplisia maka semakin besar kandungan logam mineral, garam organik, dan garam anorganiknya. Dalam hal ini, $D$. integrifolia mengandung logam mineral, garam organik, atau garam anorganik yang tinggi, namun kadar abu yang didapat masuk memenuhi syarat $\mathrm{FHI}$ yaitu kurang dari 14\% (Ditjen POM 1995). 
Tabel 1. Kadar Air Dan Kadar Abu 7 Sampel Tumbuhan

\begin{tabular}{lcc}
\hline \multicolumn{1}{c}{ Sampel } & Kadar Air (\%) \pm SD & Kadar Abu (\%) \pm SD \\
\hline A. conyzoides & $7,980 \pm 0,374^{\mathrm{b}}$ & $11,20 \pm 0,45^{\mathrm{c}}$ \\
A. lavenia & $7,973 \pm 0,119^{\mathrm{b}}$ & $9,63 \pm 0,08^{\mathrm{b}}$ \\
D. integriolia & $9,287 \pm 0,017^{\mathrm{d}}$ & $13,86 \pm 0,34^{\mathrm{e}}$ \\
G. parviflora & $8,522 \pm 0,416^{\mathrm{bc}}$ & $12,47 \pm 0,28^{\mathrm{d}}$ \\
M. michranta & $9,104 \pm 0,227^{\mathrm{cd}}$ & $11,33 \pm 0,11^{\mathrm{c}}$ \\
S. nodiflora & $7,048 \pm 0,581^{\mathrm{a}}$ & $12,23 \pm 0,17^{\mathrm{d}}$ \\
S. trilobata & $8,786 \pm 0,062^{\mathrm{cd}}$ & $9,15 \pm 0,05^{\mathrm{a}}$ \\
\hline
\end{tabular}

Tabel 2. Rendemen, Total Fenolik, dan Total Flavonoid Ekstrak Air, Fraksi Air, dan Fraksi Kloroform

\begin{tabular}{lccc}
\multicolumn{1}{c}{ Ekstrak } & Rendemen (\%) \pm SD & $\begin{array}{c}\text { Total Fenolik } \\
\text { (mg GAE/g ekstrak) } \pm \text { SD }\end{array}$ & $\begin{array}{c}\text { Total Flavonoid (mg KE/g } \\
\text { ekstrak) } \pm \text { SD }\end{array}$ \\
\hline A. conyzoides & $15,71 \pm 1,49^{\mathrm{c}}$ & $10,14 \pm 0,05^{\mathrm{b}}$ & $0,80 \pm 0,06^{\mathrm{b}}$ \\
A. lavenia & $34,18 \pm 4,75^{\mathrm{f}}$ & $12,83 \pm 0,42^{\mathrm{c}}$ & $0,48 \pm 0,11^{\mathrm{a}}$ \\
D. integrifolia & $17,53 \pm 0,87^{\mathrm{d}}$ & $17,18 \pm 0,57^{\mathrm{d}}$ & $1,41 \pm 0,09^{\mathrm{c}}$ \\
G. parviflora & $14,06 \pm 2,73^{\mathrm{b}}$ & $4,75 \pm 0,64^{\mathrm{a}}$ & $1,28 \pm 0,06^{\mathrm{c}}$ \\
M. michranta & $12,16 \pm 2,38^{\mathrm{a}}$ & $19,05 \pm 0,19^{\mathrm{e}}$ & $4,35 \pm 0,26^{\mathrm{g}}$ \\
S. nodiflora & $14,91 \pm 1,55^{\mathrm{b}}$ & $10,76 \pm 0,70^{\mathrm{b}}$ & $2,34 \pm 0,17^{\mathrm{b}}$ \\
S. trilobata & $19,77 \pm 2,51^{\mathrm{e}}$ & $9,96 \pm 0,04^{\mathrm{b}}$ & $2,03 \pm 0,04^{\mathrm{e}}$ \\
\hline
\end{tabular}

Keterangan: Huruf yang berbeda di belakang angka pada kolom yang sama menunjukkan perbedaan yang signifikan pada $\alpha=0.05$

\section{Rendemen}

Ekstraksi merupakan proses pengambilan kandungan kimia yang dapat larut sehingga terpisah dari bahan yang tidak dapat larut dengan pelarut cair. Dengan diketahui senyawa aktif yang dikandung simplisia akan mempermudah pemilihan pelarut dengan cara ekstraksi yang tepat (Ditjen POM 1995). Pemilihan metode ekstraksi didasarkan pada sifat bahan atau senyawa, efektivitas yang berkaitan dengan jumlah senyawa yang terekstraksi, dan efisiensi meliputi biaya dan waktu (Harvey 2009). Metode ekstraksi yang digunakan yaitu maserasi dengan suhu $50^{\circ} \mathrm{C}$ selama $3 \mathrm{jam}$ menggunakan pelarut air. Metode ini dipilih karena cukup mudah dilakukan dan tidak membutuhkan waktu yang lama serta air merupakan pelarut pengekstraksi yang diizinkan oleh Badan Pengawas Obat dan Makanan (BPOM) Republik Indonesia (Ditjen POM 1995). Ekstraksi pada 7 jenis tumbuhan dilakukan menggunakan pelarut air dengan perbandingan 1:10 (b/v). Rendemen ekstrak air ketujuh tumbuhan ditunjukkan pada Tabel 2. A. lavenia memiliki rendemen tertinggi yaitu sebesar $34,18 \%$ dan M. michranta memiliki rendemen terendah yaitu sebesar $12,16 \%$.

\section{Kandungan Total Fenolik}

Penentuan kandungan total fenolik dilakukan denggan metode Folin-Ciocalteu (metode kesetaraan asam galat). Reagen Folin-Ciocalteu yang mengandung fosfomolibdat-asam fosfotungstat berperan sebagai agen pengoksidasi akan bereaksi dengan senyawa fenolik di dalam ekstrak/fraksi membentuk senyawa kompleks molibdenum-tungstat berwarna biru (SingInton et al. 1999; Chen et al. 2012). Pembentukan kompleks warna biru ini sebanding dengan jumlah senyawa fenolik yang terkandung dalam suatu sampel (Dai dan Mumper 2010). Senyawa fenolik merupakan senyawa kimia yang terdiri dari gugus hidroksil $(-\mathrm{OH})$ yang terikat langsung dengan gugus hidrokarbon aromatik. Gugus hidroksil dalam senyawa fenolik dapat mendonorkan atom hidrogen melalui mekanisme transfer elektron sehingga proses oksidasi dapat dihambat, sehingga dapat digunakan sebagai antioksidan. Semua senyawa fenolik termasuk fenol sederhana dapat bereaksi dengan pereaksi FolinCiocalteu (Heim et al. 2002) Senyawa fenolik merupakan salah satu metabolit sekunder kelas besar yang terdiri dari beberapa macam, salah satunya flavonoid. 
Asam galat (asam 3,4,5-trihidroksibenzoat), senyawa fenolik yang memiliki aktivitas antioksidan yang tinggi (Marjoni et al. 2018), digunakan dalam penelitian ini sebagai standar. Total fenolik yang diperoleh pada ekstrak air 7 jenis tumbuhan ditunjukkan pada Tabel 2. Total fenolik tiap ekstrak berbeda nyata pada $\alpha=0,05$ dan total fenolik tertinggi ditemukan pada ekstrak M. michranta sebesar 19,05 mg GAE/g ekstrak dan terendah pada G. parviflora sebesar 4,75 mg GAE/ g ekstrak. Berdasarkan penelitian yang telah dilakukan oleh Idris et al. (2018), ekstrak air M. michranta memiliki total fenolik lebih kecil dibandingkan hasil penelitian ini yaitu sebesar $11,00 \mathrm{mg}$ GAE/g ekstrak. Kadar fenolik yang tinggi diharapkan akan menunjukkan aktivitas antioksidan yang tinggi.

\section{Kandungan Total Flavonoid}

Flavonoid merupakan kelompok senyawa fenolik yang paling umum ditemukan pada tumbuhan yang juga berperan sebagai antioksidan. Prinsip penentuan total flavonoid dengan $\mathrm{AlCl}_{3}$ adalah dengan pembentukan kompleks stabil antara $\mathrm{AlCl}_{3}$ dengan C-4 gugus keto dan setiap C-3 atau C-5 gugus hidroksil dari flavon dan flavonol (Chang et al. 2002) membentuk warna kuning (Popova et al. 2004).

Kuersetin digunakan sebagai standar pada penentuan total flavonoid karena kuersetin tergolong flavonol yang memiliki gugus keto pada C-4 dan gugus hidroksi pada C-3 atau C-5 yang bertetangga sehingga mudah dideteksi dengan metode ini (Azizah et al. 2014). Total flavonoid ekstrak air pada penelitian terangkum pada Tabel 2. Ekstrak pada penelitian ini memiliki total flavonoid yang berbeda nyata satu dengan lainnya dan nilai tertinggi ditemukan pada ekstrak $M$. michranta yang juga memiliki total fenolik paling tinggi. Sementara total fenolik terendah ditemukan pada $A$. lavenia. Hasil penelitian ini menunjukkan total flavonoid yang lebih tinggi dibandingkan hasil penelitian Idris et al. (2018) yaitu hanya sebesar 11,33 mg KE/g ekstrak. Total fenolik seluruh ekstrak pada penelitian ini lebih tinggi dibandingkan dengan total flavonoid. Hal ini dapat dipahami karena fenolik merupakan kelompok senyawa yang lebih besar dimana di dalam terkandung senyawa flavonoid dan senyawa fenolik lainnya. Seperti halnya total fenolik, dengan total flavonoid yang tinggi diharapkan akan memberikan aktivitas antioksidan dan antiglikasi yang tinggi.

\section{Aktivitas Antioksidan Metode DPPH}

Aktivitas antioksidan menggunakan metode penangkapan radikal bebas stabil DPPH (2,2-difenil-1pikrilhidrazil) menggunakan prinsip donasi atom hidrogen dari substansi yang diujikan pada radikal DPPH (Molyneux 2004). Aktivitas antioksidan awalnya ditentukan pada konsentrasi ekstrak $1000 \mu_{\mathrm{g} / \mathrm{mL} \text { dan }}$ hasilnya dilaporkan dalam \% penghambatan (Tabel 3). Penghambatan reaksi penangkapan radikal DPPH pada tiap ekstrak air pada konsentrasi $1000 \mu \mathrm{g} / \mathrm{mL}$ berbeda nyata pada $\alpha=0,05$ yaitu mulai dari $11,89 \%$ pada ekstrak $D$. integrifolia hingga $91,28 \%$ pada ekstrak $A$. lavenia.

Untuk memastikan aktivitas tiap ekstrak, ditentukan pula nilai $I C_{50}$ antioksidannya. Semakin rendah nilai $I C_{50}$, maka semakin tinggi aktivitas antioksidannya suatu bahan yaitu radikal bebas dapat ditangkap oleh senyawa antioksidan hanya dengan konsentrasi yang rendah. Nilai $\mathrm{IC}_{50}$ antioksidan seluruh ekstrak terangkum pada Tabel 3. Hasilnya menunjukkan bahwa nilai ini berbeda nyata satu dengan lainnya pada $\alpha=0,05$ dan nilai terendah ditemukan pada ekstrak air A. lavenia yang nilainya tidak berbeda nyata dengan ekstrak S. trilobata. Lima ekstrak tumbuhan lainnya tidak berpotensi sebagai antioksidan menurut Molyneux (2004) karena memiliki $I_{50}$ lebih besar dari $1000 \mu \mathrm{g} / \mathrm{mL}$ (Tabel 3). Aktivitas antioksidan seluruh ekstrak pada penelitian ini tidak sebaik asam askorbat sebagai kontrol positif yang memiliki nilai $I C_{50}$ sebesar $4,06 \mu \mathrm{g} / \mathrm{mL}$. 
Tabel 3. . Aktivitas Antioksidan DPPH , ABTS, dan Antiglikasi Tujuh Ekstrak Air

\begin{tabular}{|c|c|c|c|c|}
\hline \multirow[b]{2}{*}{ Ekstrak } & \multicolumn{3}{|c|}{ Aktivitas antioksidan } & \multirow[b]{2}{*}{$\begin{array}{c}\text { Inhibisi glikasi (\%) } \\
\pm \text { SD } \\
(1000 \mu g / m L)\end{array}$} \\
\hline & $\begin{array}{c}\text { Inhibisi DPPH } \\
(\%) \pm S D \\
(1000 \mu \mathrm{g} / \mathrm{mL})\end{array}$ & $\begin{array}{c}I_{50} \text { DPPH } \\
(\mu \mathrm{g} / \mathrm{mL}) \pm S D\end{array}$ & $\begin{array}{l}\text { ABTS (mg TE/g } \\
\text { ekstrak) } \pm \text { SD }\end{array}$ & \\
\hline A. conyzoides & $50,05 \pm 0,74^{d}$ & $1054,10 \pm 54,37^{c}$ & $4,51 \pm 0,05^{f}$ & $17,99 \pm 4,39^{a}$ \\
\hline A. lavenia & $91,28 \pm 1,39^{f}$ & $121,82 \pm 15,84^{b}$ & $3,38 \pm 0,17^{c}$ & $87,87 \pm 11,17^{c}$ \\
\hline D. integriolia & $11,89 \pm 2,38^{a}$ & $>2000$ & $2,08 \pm 0,73^{b}$ & - \\
\hline G. parviflora & $23,33 \pm 2,26^{b}$ & $>2000$ & $0,44 \pm 0,08^{a}$ & $90,67 \pm 8.83^{c}$ \\
\hline M. michranta & $24,01 \pm 0,20^{b}$ & $1713,95 \pm 29,27^{d}$ & $0,32 \pm 0,05^{a}$ & - \\
\hline S. nodiflora & $37,32 \pm 0,59^{c}$ & $>2000$ & $4,39 \pm 0,09^{e}$ & - \\
\hline S. trilobata & $77,96 \pm 1,32^{\mathrm{e}}$ & $148,91 \pm 12,51^{b}$ & $4,06 \pm 0,02^{d}$ & $87,38 \pm 1,76^{c}$ \\
\hline Asam askorbat & - & $4,06 \pm 0,03^{a}$ & - & - \\
\hline Aminoguanidin & - & - & - & $73,00 \pm 3,26^{b}$ \\
\hline
\end{tabular}

Keterangan:

- Huruf yang berbeda di belakang angka pada kolom yang sama menunjukkan perbedaan yang signifikan pada $\alpha=0.05$.

- Tanda (-) menunjukkan bahwa sampel tidak menunjukkan bahwa sampel tidak memiliki aktivitas antiglikasi pada $1000 \mu \mathrm{g} / \mathrm{ml}$

Aktivitas antioksidan berhubungan dengan kandungan total fenolik dan flavonoid. Namun, tidak selalu berkorelasi positif dengan kandungan total fenolik. Pada penelitian ini, tingginya kandungan total fenolik/flavonoid dari ekstrak tidak memiliki korelasi tinggi dengan aktivitas antioksidannya, terbukti dengan hasil uji korelasi Pearson dengan nilai $r=0,452$ (korelasi cukup) antara kandungan total fenolik dengan inhibisi antioksidannya dan signifikan pada level 0,05. Namun korelasi antara total flavonoid dengan antioksidannya rendah, dengan $r=-0,397$. Ekstrak $M$. michranta yang memiliki kandungan fenolik dan flavonoid tertinggi dibandingkan ekstrak lainnya, memiliki aktivitas penangkapan radikal DPPH yang lemah. Hal ini menunjukkan bahwa yang bertanggung jawab terhadap aktivitas antioksidan tidak hanya senyawa golongan fenolik dan flavonoid, namun juga senyawa lain seperti terpenoid. Salah satu terpenoid yang dilaporkan memiliki aktivitas antioksidan yang tinggi dalam $A$. lavenia dan S. trilobata adalah 11-hydroxylated kauranic acid (Ko et al. 2008; Ma et al. 2013; Fauzan et al 2017). Selain itu, aktivitas flavonoid sebagai antioksidan bergantung pada struktur molekulnya (Bhaigyabati et al. 2014).

\section{Aktivitas Antioksidan Metode ABTS}

Aktivitas antioksidan ditentukan juga menggunakan metode peredaman radikal ABTS yang dilaporkan sebagai kapasitas antioksidan pada sampel yang dinyatakan dalam mg trolox ekivalen (TE)/g ekstrak (Wang et al. 2004, Shaich et al. 2015). Aktivitas antioksidan ABTS ketujuh ekstrak disajikan pada Tabel 3. Hasil menunjukkan bahwa aktivitas antioksidan ABTS bervariasi dan berbeda secara nyata pada $\alpha=0,05$. Aktivitas antioksidan ABTS tertinggi ditemukan pada ekstrak $A$. conyzoides yang diikuti oleh ekstrak $S$. nodiflora dan $S$. trilobata. Sedangkan aktivitas antioksidan ABTS terendah ditemukan pada ekstrak $M$. michranta yang tidak berbeda nyata dengan ekstrak $G$. parvifolia.

Metode ABTS dan DPPH menggunakan spektrofotometer untuk mengukur penurunan nilai absorbansi karena menangkal radikal bebas (Shalaby dan Shanab 2013). Hasil dari kedua metode ini tidak selalu berkorelasi, hal ini disebabkan jenis radikal bebas dan mekanisme penangkapan radikal bebas yang berbeda. Berdasarkan uji korelasi Pearson diperoleh nilai $r=0,591$ (korelasi kuat) antara nilai inhibisi DPPH dengan aktivitas ABTS dan signifikan pada level 0,01. Berdasarkan hubungan aktivitas antioksidan ABTS dan kandungan fenolik dan flavonoid total menunjukkan bahwa tidak berkorelasi positif yang ditunjukkan oleh nilai $r=-0,206$ untuk total fenolik dan $-0,433$ untuk total flavonoidnya.

\section{Aktivitas Antiglikasi}

Antiglikasi merupakan zat yang dapat menghambat terjadinya reaksi glikasi protein yang menghasilkan advanced glycation end products (AGEs). AGEs diproduksi melalui reaksi Maillard yang ditandai dengan adanya asam amino teralkilasi, residu fluoresens, dan ikatan silang intramolekul maupun 
intermolekul. BSA yang merupakan sumber amina, dapat digunakan sebagai target terjadinya glikasi protein. Protein yang terglikasi akan menghasilkan radikal bebas 50 kali lebih banyak daripada protein yang tidak terglikasi (Setiawan dan Suhartono 2005).

Penentuan aktivitas antiglikasi pada ekstrak air dilakukan dengan menggunakan konsentrasi 1000 $\mu \mathrm{g} / \mathrm{mL}$ dan hasilnya dapat dilihat pada Tabel 3. Aktivitas antiglikasi ketujuh sampel berbeda nyata pada $\alpha=0,05$. Aktivitas antiglikasi tertinggi ditemukan pada ekstrak air G. parviflora yang berdasarkan analisis statistika tidak berbeda secara signifikan dengan aktivitas $A$. lavenia dan $S$. trilobata. Aktivitas antiglikasi semua sampel dibandingkan dengan kontrol positif, yaitu amionoguanidin pada konsentrasi yang sama dan menunjukkan ketiga sampel dengan aktivitas tertinggi lebih baik dibandingkan control positif. Sementara ekstrak $D$. integrifolia, $M$. michranta, dan S. nodiflora tidak dapat menghambat reaksi glikasi.

Glikasi dapat dihambat melalui beberapa mekanisme seperti menghambat produksi basa shiff dan produk amadori, menghambat perbanyakan produk amadoi pada fase selanjutnya, menghambat agregasi AGEs, mengurangi pembentukan AGEs melalui pencegahan oksidasi produk amadori dan glukosidasi katalisis logam, dan aktivitas antioksidan (Zahra et al. 2016, Dil et al. 2019). Antioksidan juga dapat menangkal radikal bebas seperti oksigen reaktif yang dapat mempercepat proses glikasi sehingga antioksidan dapat menjadi sumber antiglikasi (Ndlovu et al. 2013). Namun, nilai aktivitas antiglikasi tidak selalu berkorelasi positif dengan nilai aktivitas antioksidan. Hal ini disebabkan karena kedua aktivitas tersebut memiliki mekanisme reaksi yang berbeda. Berdasarkan uji korelasi Pearson, aktivitas antiglikasi berkorelasi dengan inhibisi oksidasi DPPH dengan nilai $r=0,603$ (korelasi kuat) pada $\alpha=0,05$, sedangkan dengan aktivitas antioksidan ABTS tidak berkorelasi ( $r=-0,019$ ). Pada penelitian ini juga tidak ditemukan hubungan antara aktivitas antiglikasi dengan total fenolik dan flavonoid yang ditunjukkan oleh nilai $r=-0,104$ untuk total fenolik dan -0,299 untuk total flavonoid.

\section{SIMPULAN}

Ekstrak ketujuh tumbuhan Asteraceae pada penelitian ini memiliki aktivitas antioksidan dan antiglikasi yang berbeda-beda. Untuk dikembangkan sebagai bahan antiglikasi dan antioksidan, ekstrak air $A$. lavenia yang memiliki $I_{50}$ antioksidan DPPH sebesar $121,82 \mu \mathrm{g} / \mathrm{mL}$ dan inhibisi glikasi $87,87 \%$, serta ekstrak air S. trilobata yang memiliki $I_{50}$ antioksidan DPPH sebesar $148.91 \mu \mathrm{g} / \mathrm{mL}$, kapasitas antioksidan ABTS 4,06 mgTE/g ekstrak, dan penghambatan glikasi 87,38\% dapat dipilih.

\section{UCAPAN TERIMA KASIH}

Penulis menyampaikan terima kasih kepada Kemenristekdikti yang memberikan dana pada Penelitian Dasar Unggulan Perguruan Tinggi (PDUPT) No. 4160/1T3.LI/PN/2019.

\section{DAFTAR PUSTAKA}

[AOAC]. The Association of Official Analytical Chemist. 2016. Official Methods of Analiysis Ed ke-20. Washington DC (US): Association of Official Analytical Chemist.

Azizah DN, Kumolowati E, Faramayuda F. 2014. Penetapan kadar flavonoid metode $\mathrm{AlCl}_{3}$ pada ekstrak metanol kulit buah kakao (Theobromo cacao L.) Kartika Jurnal IImiah Farmasi. 2(2): 45-49.

Batubara I, Mitsunaga T, Ohashi H. 2009. Screening antiacne potency of Indonesian medical plants: antibacterial, lipase inhibition, and antioxidant activities. J. Wood Sci. 55:230-235.

Bernatoniene J, Masteikova R, Davalgiene J, Peciura R, Gauryliene R, Bernatoniene R. 2011. Topical application of calendula officinalis (L);formulation and evaluation of hydrophilic with antioxidant activity. Journal of Medicinal Plant Research. 5:868877.

Bhaigyabati T, Devi P, Bag G. C.2014. Total flavonoid content and antioxidant activity of aqueous rhizome extract of three Hedychium Species of Manipur Valley. Research Journal of Pharmaceutical Biological and Chemical Sciences. 5(5): 970-976.

Chang CC, Yang MH, Wen HM, Chern JC. 2002. Estimation of total flavonoid content in propolis by two complementary colorimetric methods. Journal of Food and Drug Analysis. 10:178-182.

Chen CM, Lin CY, Lin LC, Wan TC. 2012. Antioxidant activity and total phenolic contents of various Toona sinensis extracts. African Journal of Biotechnology. 11:13831-13837.

Dai J, Mumper RJ. 2010. Plant phenolic: extraction, analysis and their antioxidant and anticancer properties. Molecules. 15:7313-7352.

Dil FA, Ranjkesh Z, Goodarzi MT, 2019. A systematic review of antiglycation medicinal plants. Diabetes \& Metabolic Syndrome: Clinical Research \& Reviews. 13(2):1225-1229 
Ditjen POM. 1995. Farmakope Indonesia. Edisi keempat. Jakarta (ID) : Departemen Kesehatan Republik Indonesia.

Erturk O, Demirbag Z. 2003. Scorzonare mollis Bieb (Compositae) bitkisinin antimikrobial aktivasi. Cerve Komura. 12:27-31.

Fauzan A, Praseptiangga D, Hartanto R, Pujiasmanto B. 2017. Characterization of the chemical composition of Adenostemma lavenia (L.) Kuntze and Adenostemma platyphyllum Cass. Earth and Environmental Sceince. 102(2018): 1-8.

Giancomoni PU, Rein G. 2001. Factors of skin aging share common mechanisms. Journal Biogerontology. 2:219-229.

Harvey D. 2009. Analytical Chemistry 2.0 Electronic versions. McGrawHill.

Heim KE, Tagliaferro AR, Bobilya DJ. 2002. Flavonoid antioxidants: chemistry, metabolism and structure-activity relationship. Journal of Nutritional Biochemistry. 13:572-584.

Idris A, Linatoc AC, Surayya MM, Aisha MA, Mohd FAB. 2018. Effect of light intensity of the total flavonoid and total phenolic contents of Mikaina mihranta and Tridax procumbens. 10(4):1-7.

Ko HH, Chang WL, Lu TM. 2008. Antityrosinase and antioxidant effect of ent-kaurane diterpenes from leaves of Broussonetia papyrifera. Journal Natural Product. 71: 1930-1933.

Kusumawati I, Djatmiko W, Rahman A, Studiawan H, Ekasari W. 2003. Eksplorasi keanekaragaman dan kandungan kimia tumbuhan obat di hutan tropis Gunung Arjuno. Jurnal Bahan Alam Indonesia. 2(3) : $100-104$.

Lee SH, Sancheti SA, Bafna MR, Sancheti SS, Seo SY. 2011. Acety/cholineterase inhibitory and antioxidant properties of Rhododendron yedoense var.Poulhanense bark. Journal of Medicinal Plants Research. 5:248-254.

Ma BJ, Wen CN, Gao Y, Ren FC, Wang F, Liu JK. 2013. Ent-kaurane diterpenoids from the Wedelia trilobata. Natural Product and Bioprospect. 3: 107111.

Marjoni MR, Nofita D, Rahmi N, Saifullah, Najia NA. 2018. Phenolic compound, flavonoids and antioxidant activity of Arum Manis leaves. International Journal of Green Pharmacy.12(3): 1-6.

Molyneux, P. 2004. The Use of The Stable Free Radical Diphenylpicrylhydrazyl (DPPH) for Estimating Antioxidant Activity. Journal of Science and Technology. 26 (2): 211-219.
Ndlovu G, Gerda F, Maleva T, Werner C, Vanessa S. 2013. In vitro determinationof the anti-aging potential of four southern african medicinal plants. BMC Complementary and Alternative Medicine. 13:1-7.

Popova M, Bankova V, Butovska D, Petkov V. 2004. Validated methods for the quantification of biologically active constituents of poplar-type propolis. Phytochemical Analysis. 15: 235-240.

Povichit GV, Phrutivorapongkul A, Suttaji M, Chaiyasut C, Leelapornpisid P. 2010. Phenolic content and in vitro inhibitory effects on oxidation and protein glycation of some Thai medicinal plants. Pak. J. Pharm. Sci. 2(4): 403-408.

Re R, Pellegrini N, Proteggente A, Pannala A, Yang $M$, Evans CR. 1999. Antioxidant activity applying an improved ABTS radical cation decolorization assay. Free Radical Biology and Medicine. 26:12311237.

Salamah N, Farahan L. 2014. Uji aktivitas antioksidan ekstrak etanol herba pegagan (Centella asiatica (L.) Urb) dengan metode fosfomolibdat. Pharmaciana. 4:23-30.

Setiawan B, Suhartono E. 2005. Stress oksidatif dan peran antioksidan pada diabetes melitus. Majalah kedokteran Indonesia. 55(2):87-90.

Shaich KM, Tian X, Xie J. 2015. Reprint of hurdles and pitfalls in measuring antioxidant efficacy a critical evaluation of ABTS, DPPH, and ORAC assays. Journal of Functional Foods. 1-15.

Shalaby EA, Shanab SMM. 2013. Review: Antioxidant compounds, assays of determination and mode of action. African Journal Pharmacy andPharmacology. 7:528-539.

Singleton VL, Orthofer R, Lamuela-Raventos RM. 1999. Analysis of total phenol and other oxidation substrates and antioxidants by means of folinciocalteu reagent. Methods in Enzymology. 299C: 152-178.

Stallings AF, Lupo MP. 2009. Practical uses of botanicals in skin care. Journal of Clinical Aesthetic Dermatology. 2:36-40.

Wang CC, Chu CY, Chu KO, Choy KW, Khaw KS, Rogers MS, Pang CP. 2004. Trolox-equivalent antioxidant capacity assay versus oxygen radical absorbance capacity assay in plasma. Clinical Chemistry. 50:952954. 
Wegiera M, Smolarz HD, Jedruch M, Korczat M, Kopron K. 2012. Cytotoxic effect of some medicinal plant from Asteraceae family on J-45.01 leukemic cell line-pilot study. Acta Policy Pharmacology. 69(2): 1-8.

Yagi S, Drouart N, Bourgaud F, Henry M, Chapleur Y, Mattar DL. 2013. Antioxidant and antiglycation properties of Hydnora johannis roots. South African Journal of Botany. 84:124-127.
Zahra U, Kartika Y, Batubara I, Darusman LK, Maddu A. 2016. Short communication: Screening the potency of Zingiberaceae leaves as antioxidant and antiaging agent. Nusantara Bioscience. 8:221-225. 